\title{
EFFECTIVENESS AND MECHANISM OF PHYSICIAN HERBS FROM KALI PUTIH BATUR BANJARNEGARA CENTRAL JAVA AGAINST DIABETIC NEPHROPATHY
}

\section{KINTOKO KINTOKO ${ }^{1}$, HARDI ASTUTI WITASARI ${ }^{1 *}$, DJATI WULAN KUSUMO ${ }^{1}$, HALID KAPRI ${ }^{1}$, TYA MULDIYANA ${ }^{1}$, SLAMET WAHYONO ${ }^{2}$}

\author{
${ }^{1}$ Departement of Pharmaceutical Biology, Faculty of Pharmacy, Ahmad Dahlan University, Yogyakarta. ${ }^{2}$ Departement of \\ Research Service, Balai Besar Penelitian dan Pengembangan Tanaman Obat dan Obat Tradisional, Tawangmangu, Indonesia. \\ Email: hardi.witasari@pharm.uad.ac.id
}

Received: 06 June 2018, Revised and Accepted: 31 August 2018

\begin{abstract}
Objectives: Complications in the kidneys (nephropathy) are one of the chronic complications of diabetes mellitus (DM) most common microvascular and estimated to reach $30-40 \%$ of all sufferers of DM. Until now there is no cure drug that can prevent diabetic nephropathy. Therefore, the handling of this issue should be done seriously, one of them through an exploration of drug discovery and drug material. Ristoja in 2015 in the ethnic Javanese Banyumasan successfully explores the types of plants, herb, and traditional medicine culture. One is conducted by the Kaliputih Traditional Medicine, Batur, Banjarnegara, Central Java. Based on the results of the interview, traditional medicine has herb for disease therapy kidney failure which consists of 11 species of plants.
\end{abstract}

Methods: The herbs were extracted by infundation method. Sprague Dawley albino male rats were divided into 3 groups (normal, positive, and negative) and 3 sample test groups with 3 different doses (18, 36, and $54 \mathrm{~mL} / \mathrm{kg}$ body weight [BW]) previously induced streptozotocin. Observations were carried on the levels blood urea nitrogen (BUN), creatinine, uric acid, and nuclear factor kappa B (NF-кB), cyclooxygenase-2 (COX-2), and transforming growth factor-beta (TGF- $\beta$ ) kidney immunohistochemically and histology analysis.

Results: Statistical results showed a significant increase of BUN levels in all dose variation groups after being given herbs, compared to the negative control group. The result of the examination of biochemical parameters of creatinine levels statistic showed significant $(\mathrm{p}<0.05)$ decrease in the dose 18 and $36 \mathrm{~mL} / \mathrm{kg}$ BW compare with the negative group. The result of the study on histopathology kidney organs there are are damages to each test in each organ that is necrosis. The result of NF- $\kappa \mathrm{B}, \mathrm{COX}-2$, and TGF- $\beta$ expression no significant decrease compared with the negative controls.

Conclusion: The herbs are not capable of nephropathy diabetic and need more research to know that activity as nephroprotective.

Keywords: Diabetic nephropathy, Herbs, Traditional medicine.

(C) 2018 The Authors. Published by Innovare Academic Sciences Pvt Ltd. This is an open access article under the CC BY license (http://creativecommons. org/licenses/by/4. 0/) DOI: http://dx.doi.org/10.22159/ajpcr.2018.v11i12.27762

\section{INTRODUCTION}

Diabetes mellitus (DM) is a chronic disease that impacts on morbidity and mortality [1]. Microvascular and macrovascular complication is a major problem on the DM patients [2]. Complications in the kidneys (nephropathy) are one of the chronic complications of DM most common microvascular $[3,4]$ and estimated to reach $30-40 \%$ of all sufferers of DM [5]. Pathophysiology of the onset of nephropathy involving hemodynamic and metabolic causing hyperglycemia and hyperlipidemia glucotoxicity trigger lipotoxicity in the kidney. High blood glucose in the kidney triggers the occurrence of inflammation and oxidative stress due to the increased production of reactive oxygen species (ROS). This can lead to hypoxia and nephropathy [6].

The main therapy for the prevention of nephropathy is controlling the levels of glucose and lipids in the blood. In addition, the use of antioxidants will suppress the production of ROS, and prevent the occurrence of oxidative stress thus preventing nephropathy [6]. Until now, there is no cure drug that can prevent diabetic nephropathy. Therefore, the handling of this issue should be done seriously, one of them through an exploration of drug discovery and drug material. The $56^{\text {th }}$ World Health Assembly issued the resolution to countries member of the World Health Organization to enhance the research of traditional medicine as well as ensure the quality, safety, and efficacy herbal medicine by setting standard of traditional medicine [7].

Riset tanaman obat dan jamu (Ristoja) in 2015 in the ethnic Javanese Banyumasan successfully explores the types of plants, herb, and traditional medicine culture. One is conducted by the Kaliputih Traditional Medicine, Batur, Banjarnegara, Central Java. Based on the results of the interview, traditional medicine has herb for disease therapy kidney failure which consists of 11 species of plants; Strobilanthes crispus as an antidiabetic [8], Orthosiphon aristatus as a nephroprotective [9], C. arabica can decrease creatinin [10], Beta vulgaris as cholesterol-lowering [11], Saccharum officinarum as a high-density lipoprotein enhancer [12], Canna edulis can decrease creatinine levels [13], Curcuma xanthorriza, Curcuma mangga, and Curcuma domestica as an antioxidant, anti-inflammation and nephroprotective [14], and Averrhoa bilimbi as antihyperlipidemic [15] and srintil hutan that unknown morfo-anatomy or Latin name.

\section{MATERIALS AND METHODS}

\section{Materials}

The herb of Kaliputih, Batur, Banjarnegara, Central Java used empirically for the therapy of renal failure. Streptozotocin kit, ureum kit, creatinin kit, uric acid kit, blood urea nitrogen (BUN) kit, antibodies of transforming growth factor-beta (TGF- $\beta$ ), NF-kB, and cyclooxygenase-2 (COX-2). Citrate buffer $\mathrm{pH} 4.5$, ethanol, 3,3'-diaminobenzidine staining, xilen, hydrogen peroxide, pioglitazon were used.

\section{Instrumentation}

Spectrophotometer UV-vis (Shimadzu, Japan), Rotary evaporator R-144 (Buchi Labortechnik AG, Switzerland), 100-1000 $\mu$ l micropipette (Eppendorf) were used. 


\section{Methods}

The herb that will be tested is provided based on information from physician of Kaliputih and taken directly from physician domicile. Herbs were determined in Biology Laboratory of Universitas Ahmad Dahlan, Yogyakarta, Indonesia, and numbered 092/lab.bio/B/VII/2018. All the ingredients washed clean, pounded, and boiled with 2 liters of water to half. Sparaguey Dawley rat males, 8 weeks (220-260 g) obtained from Badan Pengawas Obat dan Makanan. Before used, rats acclimated in cages for 1 week. The rat was weighed and grouped randomly into six groups, and each group consists of 5 rats. In Group II-VI rats were inducted with streptozotocin dose of $40 \mathrm{mg} / \mathrm{kg}$, whereas rats of Group I were just given per oral (po) the saline solution. The induced rats were observed to gain information on the increasing level of blood sugar for 1 week.

\section{Activity test of herbal drink}

Rat with blood sugar levels of $>350 \mathrm{mg} / \mathrm{dL}$ were included in testing. Group I was a normal control (given saline peroral). Group II was a negative control (streptozotocin). Group III was the positive control (given a streptozotocin and pioglitazon $2.4 \mathrm{mg} / \mathrm{kg}$ po). Groups IV, V, and VI in a row were given herbs treatment doses of 18,36 , and $54 \mathrm{~mL} / \mathrm{kg}$ po after being given the streptozotocin. The treatment was given for 15 days in accordance with the therapy conducted by physician. For 15 days, the signs of DM as the amount of water intake, food, weight, urine $\mathrm{pH}$, and volume of urine were observed. Fasting blood sugar levels were determined on a day-to- $0,7^{\text {th }}$, and $15^{\text {th }}$ using a spectrophotometer with a kit of glucose.

\section{Examination ofbloodbiochemicalparameterusingspectrophotometer} UV-vis

Examination of biochemical parameters using blood serum was taken from vena jugularis. Measured parameters include blood glucose levels and renal function (BUN, creatinine, and uric acid levels) using spectrophotometric Microlab 300. Total of $10 \mu \mathrm{L}$ serum was added with the reagent kit and prepared according to the kit procedure

\section{Examination of histopathology organ}

After the blood was taken, the rats were sacrificed for the kidney. Histopathology examination was conducted at the Veterinary Faculty of Gadjah Mada University.

\section{Immunohistochemical organ}

Immunohistochemical analysis of TGF- $\beta, N F-k B$, and COX-2 of kidney was conducted at the Veterinary Faculty of Gadjah Mada University.

\section{Ethical considerations}

Ethical approval was granted by the Ethics Committee, Universitas Ahmad Dahlan, Yogyakarta, Indonesia, number 011609136.

\section{Statistical testing}

The resulted data were quantitative, qualitative, and semi-quantitative data. Quantitative and semiquantitative data were tested preliminarily with Kolmogorov-Smirnov for normality and Levene Test for homogeneity. Parametric data were tested with ANOVA followed by t-test, while non-parametric data were tested with Kruskal-Wallis followed by Mann-Whitney test. Meanwhile the qualitative fund was conducted through descriptive analysis. The statistical level of significance was set at $95 \%(\mathrm{p}<0.05)$

\section{RESULTS AND DISCUSSION}

\section{Measurement of blood biochemical parameters spectrophotometer} UV-vis

The result is as illustrated in Kintoko et al., where there is a significant rise in glucose levels of the animals, before and after the test that inducted streptozotocin that animals which had increased blood glucose levels by streptozotocin were given renal failure for 15 days. The results show a significant decrease in the dose of 36 and $54 \mathrm{~mL} / \mathrm{kg}$ body weight (BW) compared with the negative control group [16].

Before testing, streptozotocin-induced to obtain diabetic rats. In this study, a dose was used to induce the test animals through intraperitoneal at $40 \mathrm{mg} / \mathrm{kg}$ [17]. After 1 week, the rats will make a disruption of the response to glucose and the sensitivity of $\beta$ cells to glucose. From the results of previous research by Kintoko et al. that blood glucose level of test animals, there is a significant increase of blood glucose level after induced streptozotocin dose $40 \mathrm{mg} / \mathrm{kg}$ BW [16].

Streptozotocin is widely used as diabetic nephropathy. However, it could also be cytotoxic to kidneys making it difficult to distinguish between diabetic-related nephropathy and streptozotocin-induced nephropathy. One study reported that the streptozotocin-induced diabetic rat was not suitable for long-term studies because of progressive renal tumorigenesis. In addition, weight loss, respiratory distress, and rapid glycemic shifts resulting in life-threatening hypoglycemia. Nephrotoxicity in the form of transient proteinuria, azotemia, abnormalities of tubular function, and acute renal failure was described as squamous metaplasia may be an important part of streptozotocin renal toxicity [18]. However, Evan et al. reported that, in contrast with alloxan, streptozotocin caused no detectable renal injury at the dose of $60 \mathrm{mg} / \mathrm{kg}$ which was approximated as the one we used [19].

Renal function test (Table 1) was to measure the levels of BUN, uric acid, and creatinine in blood. Statistical results showed a significant increase of BUN levels in all dose variation groups after being given herbs, compared to the negative control group. On examination of creatinine levels statistic showed significant decrease in the dose 18 and $36 \mathrm{~mL} / \mathrm{kg} \mathrm{BW}$ compare with the negative group. Serum uric acid was not significantly different between hyperglycemic and healthy control groups.

Measurement of BUN, creatinine and uric acid levels to see parameters of renal function induced by streptozotocin and given renal failure with three different doses in Table 1. On examination of uric acid levels that may affect 3 groups comparable to normal controls and controls negative. On examination of BUN levels, there was a significant increase of 3 groups using negative controls. This increase in BUN is similar to that of Adam et al. in which 0 . stamineus can significantly increase glucose, albumin, urea and creatinine levels. Elevated BUN levels are triggered because $O$. stamineus plant has an effect as a diuretic. The diuretic effect can be affected by the high electrolyte effect of the herb and leading to the renal epithelium. Diuretic activity will inhibit water reabsorption to the tubular epithelium. The active compound of the 0 . stamineus plant is known to have an effect as a diuretic such as flavonoids glycosides and saponins [20].

Table 1: Results of renal function parameters measurements

\begin{tabular}{llll}
\hline Treatment & BUN (mg/dL) & Uric acid (mg/dL) & Creatinine (mg/dL) \\
\hline Normal control & $179.05 \pm 55.43$ & $5.12 \pm 0.57$ & $14.65 \pm 4.58$ \\
Negative control & $280.27 \pm 123.95$ & $4.43 \pm 0.88$ & $33.47 \pm 21.22$ \\
Positive control & $231.79 \pm 36.6$ & $4.79 \pm 1.06$ & $11.03 \pm 2.75$ \\
Dose $18 \mathrm{~mL} / \mathrm{kg} \mathrm{BW}$ & $329.63 \pm 59.95^{\#}$ & $3.77 \pm 0.57$ & $18.3 \pm 7.41^{\#}$ \\
Dose $36 \mathrm{~mL} / \mathrm{kg} \mathrm{BW}$ & $321.98 \pm 109.54^{\#}$ & $4.41 \pm 1.26$ & $18.98 \pm 8.88^{\#}$ \\
Dose $54 \mathrm{~mL} / \mathrm{kg} \mathrm{BW}$ & $363.1 \pm 134.38^{\#}$ & $21.82 \pm 5.19$ \\
\hline
\end{tabular}

All the data were shown at the mean $\pm S D, n=5$. *Significant different from normal control group, $p<0.05$. \#Significant different from negative control group, $p<0.05$.

SD: Standard Deviation, BUN: Blood Urea Nitrogen, BW: Body Weight. 
At the creatinine level, 3 test groups were compared with normal control and negative control. There was a significant decrease in the dosage of 18 and $36 \mathrm{~mL} / \mathrm{kg}$ BW herbs compared with the negative controls. Decreased levels of creatinine caused flavonoids contained in some mixture of herbs. The use of water solvent in the preparation of the herb increases the solubility of flavonoids. In addition, the curcumin content of some plants of the Curcuma genus that is used as a mixture of potions proven to decrease creatinine significantly. From the 11 kinds of plants, only known 5 plants that potentially improve kidney function seen from its ability to reduce levels of uric acid, creatinine, and serum ureum 5 crops such as $S$. crispus, O. stamieus, C. arabica, C. xanthorriza, and C. domestica.

\section{Histopathological examination of kidney}

The results of the renal histopathologic study (Fig. 1) of all treatments showed the presence of necrotic focal damage in the tubule epithelium. The cause is due to acute cell damage or trauma such as lack of oxygen, extreme temperature changes, increased excessive antioxidant levels, and mechanical injury. These cell deaths occur uncontrollably which can cause cell damage or an inflammatory response. Damage on kidney organ will interfere with most kidney function. The kidneys play an important role in the release of toxic substances or toxins, maintaining of fluid balance, maintaining a balance of acid and alkaline levels from body fluids, maintaining the balance of salts and other substances in the body, so in this case the kidneys play a role in the release of substances the ingredients contained in the herbal concoction consumed by rats.In addition, materials that have activities such as sulfonamide antibiotics and nonsteroidal anti-inflammatory drugs such as diuretics can damage tubule epithelial cells. The ingredients that have diuretic effects in renal failure include S. crispus [21], O. stamineus [20], S. officinarum [12], and C. domestica [22].

Kidney damage can be exacerbated by precipitation of calcium oxalate crystals in the kidney tubules. Excessive oxalate intake is known to come from A. bilimbi. The star fruit is very acidic and is usually used for traditional therapies of hyperlipidemia, hypertension, and diabetes [23]. However, from its use, there are side effects on the kidney and nervous system [24]. Oxalic acid in star fruit has direct toxic effects on renal tubules and renal interstitium. Facilitate the formation of oxalic crystals by endocytosis by renal epithelial cells and increases the incidence of proliferative responses. These crystals also stimulate specific genes in renal tubular cells, including connective tissue, and growth factor genes that lead to interstitial fibrosis. All patients who have a history of consuming star fruit juice have calcium oxalate crystals in their urine. Moreover, patients undergoing biopsy have polarized intracellular oxalate crystals [25].

\section{Immunohistochemistry of renal organs}

The result of nuclear factor kappa B (NF- $\mathrm{kB}$ ) expression (Fig. 2) did not show any significant difference from each test group. Of the 11 kinds of mixed plants from the herbs known coffee has kahweol compounds that are able to inhibit TNF- $\alpha$ expression induced through the NF- $\mathrm{KB}$ activation pathway. In general, kahweol is an anti-inflammatory and anti-atherosclerotic agent by affecting the expression and interaction of molecular adhesion on endothelial cells [26]. The activation of the NF- $\kappa B$ pathway generally underlies the inflammatory process and improved translocation of NF- $\mathrm{KB}$. Leukocytes from diabetes patients by AGEs or ROS are oxidative stress. Increased levels of glucose are known to produce ROS in mesangial cells, which play a role in macrophage infiltration of renal failure and activate the NF- $\mathrm{kB}$ pathway. The NF-kB pathway plays a role in macrophage infiltration of gene expression, and inflammation of the kidney due to hyperglycemia [27].

The results of COX-2 expression (Fig. 3) and TGF- $\beta$ expression (Fig. 4) showed no significant differences from each test group. Of the 11 kinds of plant mixture of the kidney failure herb known kinir, white turmeric, and temulawak contain kurkumin. According to Khajehdehi curcumin is able to inhibit cytokines and the production of TGF- $\beta$ from various

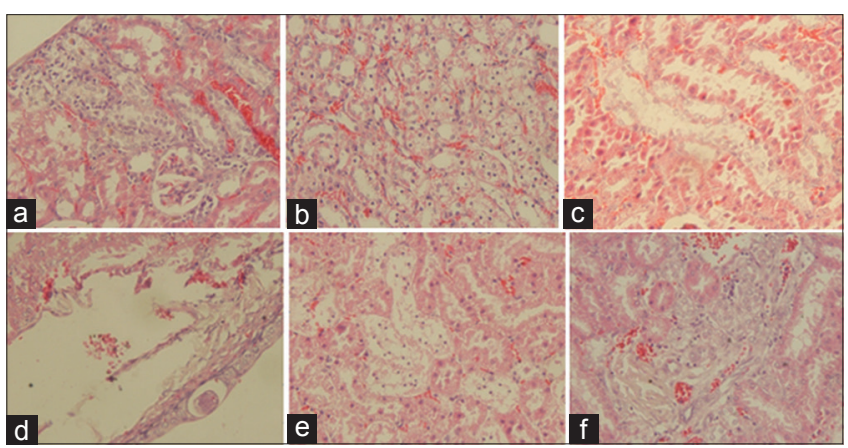

Fig. 1: Histopathological images of renal tissue sections of normal group (a), negative group (b), positive group (c), dose $18 \mathrm{ml} / \mathrm{kg}$ body weight (BW) (d), dose $36 \mathrm{ml} / \mathrm{kg} \mathrm{BW} \mathrm{(e),}$ dose $54 \mathrm{ml} / \mathrm{kg} \mathrm{BW}$ (f)

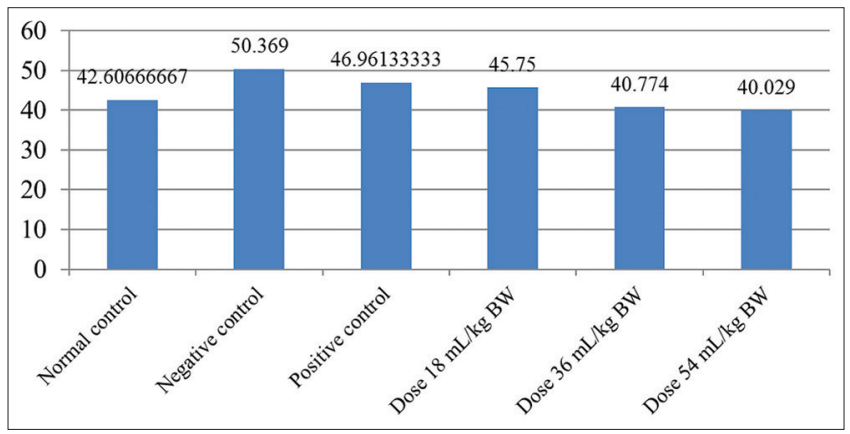

Fig. 2: The result of nuclear factor kappa B parameters measurement

factors involved in chronic kidney disease and primary and secondary glomerulonephritis pathogenesis [28].

Rosmarinic acid is a phenolic compound and one of the components of the extraction on the 0 . stamineus [29]. The results of research were conducted by Domitovic et al. in cisplatin-induced mice, rosmarinic acid function as nephroprotective [30]. In other plants such as ginger, white turmeric and turmeric contain curcumin compounds capable of inhibiting NF- $\mathrm{KB}$ activation in the kidney in NRK-52E epithelial cells in vitro and have been shown to decrease NF- $\mathrm{KB}$ expression in kidney organs in diabetic mice [31]. Curcumin activity prevents the occurrence of diabetic nephropathy by inhibiting oxidative stress due to hyperglycemia that is able to activate the NF- $\kappa \mathrm{B}$ pathway. With the inhibition of the NF- $\mathrm{KB}$ pathway, TGF- $\beta$, ET-1, and eNOS are not expressed in the mesangial cells [32].

\section{CONCLUSION}

Measurement of blood biochemical parameters showed significant increase of BUN levels in all dose variation groups after being given herbs, compared to the negative control group. The result of the examination of biochemical parameters of creatinine levels statistic showed significant $(p<0.05)$ decrease in the dose 18 and $36 \mathrm{~mL} / \mathrm{kg}$ BW compare with the negative group. Serum uric acid was not significantly different between hyperglycemic and healthy control groups. Study on histopathology kidney organs there are damages to each test in each organ that is necrosis. Expressions of NF- $\mathrm{kB}, \mathrm{COX}-2$, and TGF- $\beta$ showed no significant differences from each of the test dose groups compared with negative controls. Need more research to know that activity as nephroprotective.

\section{ACKNOWLEDGEMENTS}

Our greatest gratitude to The Indonesian Health Ministry, for their assistance and financial supports, and our thanks also to the relevant parties who help us upon the completion of this research. 


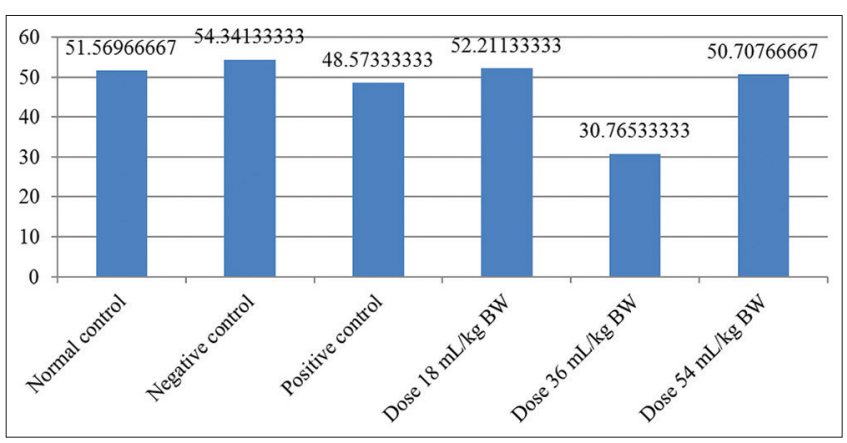

Fig. 3: The result of cyclooxygenase-2 parameters measurement

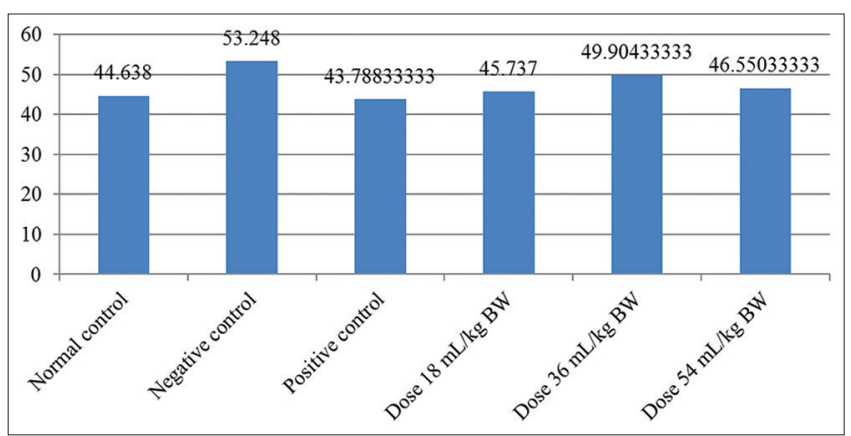

Fig. 4: The result of transforming growth factor-beta parameters measurement

\section{AUTHOR'S CONTRIBUTIONS}

The authors thank The Indonesian Health Ministry for the financial support and the management of Sardjito Hospital for their help with examination of histopathology organ. This study was designed and coordinated by Kintoko, Sitarina Widyarini, and Hardi Astuti Witasari as the principal investigators provided conceptual and technical guidance for all aspects of the project. Nurkhasanah developed the theoretical framework. Slamet Wahyono supervised the project. Djati Wulan Kusumo, Halid Kapri, Tya Muldiyana, Hasni Pulhehe, Yuli Nurullaili Efendi, Tri Puspita Yuliana and Urmatul Waznah performed the experiment, analyzed data, and wrote the manuscript.

\section{CONFLICTS OF INTEREST}

The authors do not have any conflicts of interest to declare.

\section{REFERENCES}

1. Patel DK, Kumar R, Prasad SK, Sairam K, Hemalatha S. Antidiabetic and in vitro antioxidant potential of Hybanthus enneaspermus (Linn) F. Muell in streptozotocin-induced diabetic rats. Asian Pac J Trop Biomed 2011;1:316-22.

2. Prabhakar K. Pathophysiology of secondary complicaions of diabetes mellius. Asian J Pharm Clin Res 2016;9:32-6.

3. Stitt-Cavanagh E, MacLeod L, Kennedy C. The podocyte in diabetic kidney disease. ScientificWorldJournal 2009;9:1127-39.

4. Luis-Rodríguez D, Martínez-Castelao A, Górriz JL, De-Álvaro F, NavarroGonzález JF. Pathophysiological role and therapeutic implications of inflammation in diabetic nephropathy. World J Diabetes 2012;3:7-18.

5. Abushady MM, Fathy GA, El-Alameey IR, Abbas MA, Galal EM, Nasr SA. Urinary liver-type fatty acid-binding protein as a marker for early diagnosis of diabetic nehropathy in Type 1 diabetic children. Asian J Pharm Clin Res 2018;11:329-32.

6. Gustafsson AB, Gottlieb RA. Autophagy in ischemic heart disease. Circ Res 2009; 104:150-8.

7. Anonim RD. Farmakope Herbal. Jakarta: Departemen Kesehatan RI; 2009.

8. Nurraihana H, Norfarizan-Hanoon NA. Phytochemistry, pharmacology and toxicologyproperties of Strobilanthes crispus. Int Food Res J 2013;20:2045-56.
9. Kannapan N, Madhukar A, Mariymmal, Uma-Sindhura P, Mannavalan R. Evaluation of nephroprotective activity of Orthosiphon stamineus Benth extract using rat model. Int J Pharm Tech Res 2010;2:209-15.

10. Haque MR, Ansari SH, Rashikh A. Coffea Arabica seed extract stimulate the cellular immune function and cyclophosphamide-induced immune suppression in mice. Iran J Pharm Res 2013;12:101-8.

11. Panee J. Potential medicinal application and toxicity evaluation of extract from bamboo plants. J Med Plants Res 2015;9:681-92.

12. Karthikeyan J, Samipillai SS. Sugarcane in therapeutics. J Herba Med Toxicol 2010;4:9-14.

13. Fariah G, Dharmawan E. Meningkatkan kerja fungsi ginjal dengan konsumsi tepung ganyong (Canna edulis Kerr). Media Farmasi Indonesia 2013;2:29-39.

14. Venkatesan N, Punithavathi D, Arumugam V. Curcumin prevents adriamycin nephrotoxicity in rats. Br J Pharmacol 2000;129:231-4.

15. Pushparaj P, Tan $\mathrm{CH}$, Tan BK. Effects of Averrhoa bilimbi leaf extract on blood glucose and lipids in streptozotocin-diabetic rats. J Ethnopharmacol 2000;72:69-76.

16. Kintoko WS, Witasari HA, Kusumo DW, Kapri H, Pulhehe H, Yuliana TP, et al. Uji in Vivo Efektivitas dan Mekanisme aksi Ramuan Gagal Ginjal Akibat Komplikasi Diabetes Dari Pengobat Tradisional Asli Kaliputih, Batur, Banjarneggara, Jawa Tengah. Yogyakarta: Kementrian Kesehatan RI; 2016.

17. Nugroho AE. Hewan percobaan diabetes mellitus: Patologi dan mekanisme aksi diabetogenik. Biodiversitas 2006;7:378-82.

18. Javadi S, Asri-Rezaei S, Allahverdizadeh M. Interrelationship of ßeta2 microglobulin, blood urea nitrogen and creatinine in streptozotocininduced diabetes mellitus in rabbits. Vet Res Forum 2014;5:7-11.

19. Evan AP, Mong SA, Gattone VH, Connors BA, Aronoff GR, Luft FC, et al. The effect of streptozotocin and streptozotocin-induced diabetes on the kidney. Ren Physiol 1984;7:78-89.

20. Adam Y, Somchit MN, Sulaiman MR, Nasaruddin AA, Zuraini A, Bustaman AA, et al. Diuretic Properties od Orthosiphon stamineus Benth. J Ethnopharmacol 2009;1:14

21. Fadzelly AB, Asmah R, Fauziah O. Effects of Strobilanthes crispus tea aqueous extracts on glucose and lipid profile in normal and streptozotocin-induced hyperglycemic rats. Plant Foods Hum Nutr 2006;61:7-12.

22. Devaraj S, Ismail S, Ramanathan S, Marimuthu S, Fei YM. Evaluation of the hepatoprotective activity of standardized ethanolic extract of Curcuma xanthorrhiza Roxb. J Med Plants Res 2010;4:2512-7.

23. Tan BK, Tan CH, Pushparaj PN. Anti-diabetic activity of the semipurified fractions of Averrhoa bilimbi in high fat diet fed-streptozotocininduced diabetic rats. Life Sci 2005;76:2827-39.

24. Neto MM, da Costa JA, Garcia-Cairasco N, Netto JC, Nakagawa B, Dantas M, et al. Intoxication by star fruit (Averrhoa carambola) in 32 uraemic patients: Treatment and outcome. Nephrol Dial Transplant 2003; 18:120-5.

25. Bakul G, Unni VN, Seethaleksmy NV, Mathew A, Rajesh R, Kurien G, et al. Acute oxalate nephropathy due to "Averrhoa bilimbi" fruit juice ingestion. Indian J Nephrol 2013;23:297-300.

26. Kim HG, Kim JY, Hwang YP, Lee KJ, Lee KY, Kim DH, et al. The coffee diterpene kahweol inhibits tumor necrosis factor-alpha-induced expression of cell adhesion molecules in human endothelial cells. Toxicol Appl Pharmacol 2006;217:332-41.

27. Patel S, Santani D. Role of NF-kappa B in the pathogenesis of diabetes and its associated complications. Pharmacol Rep 2009;61:595-603.

28. Khajehdehi P. Turmeric: Reemerging of a neglected Asian traditional remedy. J Nephropathol 2012;1:17-22.

29. Amoah SK, Sandjo LP, Kratz JM, Biavatti MW. Rosmarinic acid-pharmaceutical and clinical aspects. Planta Med 2016;82:388-406.

30. Domitovic R, Potocnjak I, Orlic ZC, Skoda M. Nephropotective activities of rosmarinic acid against cisplatin-induced kidney injury in mice. Food Chem Toxicol 2014;66:321-8.

31. Pan Y, Zhang X, Wang Y, Cai L, Ren L, Tang L, et al. Targeting JNK by a new curcumin analog to inhibit NF-kB-mediated expression of cell adhesion molecules attenuates renal macrophage infiltration and injury in diabetic mice. PLoS One 2013;8:e79084.

32. Chiu J, Khan ZA, Farhangkhoee H, Chakrabarti S. Curcumin prevents diabetes-associated abnormalities in the kidneys by inhibiting p300 and nuclear factor-kappaB. Nutrition 2009;25:964-72. 